\title{
Erindring, ideologi og identitet i Don DeLillos Underworld
}

"En begivenheds kraft kan strømme fra dens uopløselige kerne, alle de grusomme og uhåndgribelige elementer der ikke stemmer overens, og det får dig til at gøre morkelige ting, og fortcelle dig selv historier, og opbygge trovcerdige verdener"

Don DeLillo

I en stemning af tristesse og melankoli ser Underverdens centrale person, Nick Shay, der som romanens eneste figur lejlighedsvis nyder det privilegium at optræde som jeg-fortæller, tilbage på sit liv. I denne selvbiografiske status anskueliggøres romanens syn på 40 års amerikansk historie.

I det ydre er Nicks biografi en amerikansk succeshistorie: Et liv, der begyndte med alle odds mod sig, men som udviklede sig til en god og respektabel karriere i affaldsindustrien. Fra sit kontor ser han, klædt i jakkesæt, ud af vinduet fra den skyskraber, som hans firma, Waste Containment, ligger i. Men der er en undertone af tristhed midt i den sociale opstigning fra kriminalitet og underklasse til et liv i det godes tjeneste som "affaldsanalytiker «, ${ }^{1}$ der rejser rundt til internationale kongresser. Han reagerer "stadig« på følelsen af »at være på et kontor, at gå i et nypresset jakkesæt« (U, p. 784).

I sidste kapitel skildrer Underverden en mand, der gør status over et liv som socialt, materielt og moralsk blev bedre end forventet, men til gengæld aldrig helt hans eget. I sine mest pessimistiske stunder overvejer han muligheden for at overlade det hele - børn, biler og hus - til konen Marian

1. Don DeLillo: Underverden, på dansk ved Jørgen Nielsen, Kbh. 1998, p. 782. Denne udgave forkortes i det efterfølgende $U$. 
og hendes elsker Brian, eftersom intet har tilhørt ham i anden forstand end, at han har udfyldt blanketterne ( $U$, p. 774). Hans aktiviteter har karakter af terapi: Tager ind på kontoret, åbner post, sætter reoler op i hjemmet og flytter lidt rundt på bøgerne, men med en længsel i kroppen efter ungdommens dage, da han var »ubetænksom og virkelig« ( $U$, p. 787). Omvendt er han naturligvis ikke blind for det sunde islæt af overlevelsesevne, han har dokumenteret: „føler en stille form for styrke fordi jeg har klaret det og er sluppet godt fra det, har klaret det og vundet, gået svag ind og kommet stærk ud«. ( $U$, p. 781) Men hvad er kernen i denne status over livet? Svaret findes i overvejelserne over faderens pludselige forsvinden fra familien, da han en dag gik ud efter cigaretter, men aldrig kom tilbage. Uanset hvilke motiver og hvilken karakter faderen, Jimmy Constanza, havde, blev det nederlag, det påførte Nick og broderen Matt, ikke mindre.

Da Nick skriver sin biografi i tankerne, nægter han, hvad hans liv og karriere, der udstråler succes, nemt kunne forlede til, nemlig at skrive en harmonisk livshistorie, der fortrænger nederlagene eller ophøjer dem til noget, der set under ét hæfter en højere mening til. Hverken de personlige nederlag eller de uindfriede længsler skrives ud af livshistorien, som det kunne være fristende at gøre retrospektivt. Livsbiografiens mange modsatrettede fragmenter harmoniseres ikke i én historie, men får lov til at blive stående i deres indbyrdes uforsonlige egenart. Han fortæller sin historie, men han gør den ikke til én historie. Nicks måde at gøre sit liv op på, hvor hændelser, længsler og nederlag får lov til at stå nøgternt ved siden af hinanden, giver troværdighed til hans selvkarakteristik i begyndelsen af romanen, at han lever i »realiteternes verden«. ( $U$, p. 78) Et overraskende eksempel på hans bevidsthed om nederlag, som samtidig hænger sammen med den nationale historie, er Nicks køb af den famøse baseball, som Bobby Thomson slog, da han lavede sin home run i den berømte kamp mellem Dodgers og New York Giants den 3. oktober 1951. Han har købt bolden for en formue, men kan ikke altid lige tydeligt huske, hvorfor han købte den. Den er først og fremmest et vidnesbyrd om New York Giants sejr over Dodgers'. Men Nick twister historien, så den også bliver en historie om kasteren, pitcheren Branca, altså taberen: »Jo, jeg købte ikke bolden på grund af den storhed og dramatik der knytter an til den. (U,p. ...). Det handler kun om at tabe«. ( $U$, p. 93) På samme måde som tabene er indskrevet i Nicks succesfulde liv er tabet repræsenteret i den baseball, som er symbolet på Giants sejr.

Den måde, som Nick forvalter sin historie på, er en fortættet model for den måde som Underverden skriver både individuel og kollektiv historie. En model for, hvordan den fortæller historier. Underverden er en erindringsroman på sporet af en amerikansk identitet, spækket med billeder fra den personlige og kollektive historie fra det seneste halve århundrede. 


\section{Den store og den lille historie}

Historierne rummer hinanden: Den globale rummer den lokale, den offentlige den personlige og den politiske den eksistentielle. Når der tit henvises til det faktum, som det også gøres i Underverden, at alle mennesker kan huske, hvor de var, da præsident J.F. Kennedy blev skudt, handler det netop om, hvordan den store historie bruges, ikke til at huske den store historie, men den lille personlige, dvs. hvor man selv var, da der skete et eller andet vigtigt ude i den store verden.

Underverden er som en roman om den globale ideologiske og militære spænding mellem USA og Sovjetunionen, der truede med at lægge kloden øde, i sagens natur fyldt med henvisninger til den store mediedækkede historie i perioden. Men den store historie fortælles gennem en mangfoldighed af små personlige historier. De store historiske begivenheder fortælles altså ikke kun for deres egen skyld, og flere gange bliver man i tvivl om, hvor vigtige de egentlig var, når det kommer til stykket. Den store historie er en blanding af dødelig alvor og lettere forstyrrende baggrundstøj. For hvad er det, der gør indtryk, når alt kommer til alt? Den tv-transmitterede virkelighed, uanset dennes væsentlighed i global sammenhæng, eller det personligt oplevede og erfarede. Den home run som Bobby Thomson slog den 3. oktober 1951 "trænger«, som det hedder programmatisk for romanens menneske- og historiesyn, "mere varigt ind under huden end de store strategiske afgørelser som træffes af fremtrædende ledere, stålsatte generaler med deres solbriller«. ( $U$, p. 54) Romanens handling og situationer er rettet mod dét i menneskelivet, der går rent ind i erindringens sorte boks og dermed i identiteten. Typisk for dens evne til kort og fyndigt at samle de store eksistentielle temaer i én sætning, hedder det: "En mand tager sin søn med til en kamp, og tredive år senere er det den de taler om når det stakkels gamle fjols ligger på sit yderste på sygehuset«. (U, p. 27) Det er den indsigt Underverden har taget den fulde konsekvens af, når den skriver 40 års historie gennem én baseball. Det er de to baseballspillere, Bobby Thomson og Ralph Branca, der repræsenterer den historiske kontinuitet i de mange fotografier, hvor de står ved siden af de skiftende præsidenter. Disse har åbenbart opfattet spillerne som yderst velegnede ikoner at skrive historie med.

Underverden er opbygget som en sammenvævning af mange forskellige historier, hvoraf nogle stedvist berører hinanden. De enkelte historier påbegyndes, afbrydes og genoptages gennem en periode, der strækker sig fra efteråret 1951 til begyndelsen af 1990'erne. Romanen begynder med begyndelsen, dvs. den 3. oktober 1953, og ender tæt på vor tid, men mellem fortællingens to tidspoler bevæger romanen sig gradvist tilbage i tiden. Efter indledningskapitlet om baseballkampen i 1951, springes frem til foråret og 
sommeren 1992, hvorefter fortællingen bevæger sig ned gennem årtierne, hvis endelige slutpunkt er den unge Nicks fatale mord. Klara Sax, Nick og Matt Shay, Albert Bronzini, Alma Edgar, John Edgar Hoover, Marvin Lundy, Chuckie Wainwright, Ismael Muños: Deres livshistorier skrives tidsmæssigt baglæns, således at de får karakter af en gradvis arkæologisk fortidsafdækning og tilvejebringelse af forudsætningerne for kronologisk set senere hændelser i deres liv, som vi altså har hørt om tidligere i romanen. Flere af personerne stammer oprindeligt fra samme kvarter og har haft berøring med hinanden. På den måde konvergerer de nutidige historier via romanens komposition delvist i en fælles fortid. Hændelser og begivenheder, som personerne tidligere har erindret, oplever vi senere indefra, dog i mange tilfælde stadig fortalt i datid. Det gælder f.eks. et bal på Plaza Hotel i New York i 1966, som den ældre Klara Sax ikke rigtig kan eller har lyst til at huske.

\section{Erindring}

I Jim Jarmusch' film Mystery train tager en af filmens personer billeder af et hotelværelse. Da han bliver spurgt, hvorfor han taget billeder af noget så intetsigende og almindeligt, lyder svaret, at det er nemt nok at huske de store seværdigheder, men at det netop er de små banale ting, vi glemmer. Pointen er i slægt med intentionen i Underverden, hvor det flere gange siges at det er det, der befinder sig lige foran os, som vi overser. De største hemmeligheder ser os lige i øjnene. I nogle romanens mest komplicerede og mest ambitiøse steder prøver den at komme ned på erindringens mikroniveau; ned hvor identiteten dannes.

Da Nick på et tidspunkt opsøger Klara Sax, fortæller hun, at hendes eksmand Albert er død. Nick kendte kun lige akkurat Albert, men konstaterer alligevel, at han gennem årene alligevel er dukket op i erindringen på samme måde som »visse steder« $(U$, p. 70$)$ og gader ledsager tankerne. Det, der tales om, er steder, mennesker og gader, der tilsyneladende umotiveret dukker op i tankerne, og som spiller en rolle i erindringen. Der tilføjes to oplysninger, som måske har en vis forklarende kraft. For det første finder erindringen sted på samme måde, som visse steder bliver vigtigere i ens tanker, som tiden går. Det klassiske sted kunne være skolegården, som i barndommen aldrig blev perciperet på afstand, men kun gennem selvforglemmende leg, boldspil og løb, og derfor er identisk med ens personlige historie på en mere fundamental måde end steder, der i en senere alder er oplevet gennem arbejde, distance og refleksion. For det andet finder erindringen sted på et bestemt tidspunkt, nemlig om morgenen, dvs. i en tilstand mellem søvn og bevidsthed. Erindringen kædes således sammen med den fremadskridende alder og 
søvnlignende tilstande. Det, der i sig selv forekommer nærmest ligegyldigt, viser sig at være en identitetsskabende faktor. Noget almindeligt uden for én selv, der er en del af én selv.

Underverden er en statusroman, der interesserer sig for brudflader i historien og erindringen, dvs. de steder, hvor det bliver tydeligt, at selvforståelsen og identiteten har karakter af en historisk bestemt konstruktion. Don DeLillo går efter sprækkerne. Efter 40 års militæroprustning og spild mellem de to supermagter spørges: »er der nogen der kan huske hvorfor vi gjorde alt det her?« $(U$, p. 771$)$ Det er ikke svaret, men det, at spørgsmålet stilles, der er interessant. At de gamle svar er svære at huske afslører, at epokens selvforståelse, som i dette tilfælde legitimerede oprustning, retrospektiv set hverken virker afgørende eller overbevisende, men snarere konform og konventionel.

Det eneste sted i romanen, hvor der henvises til grundene til oprustning, er, da Matt Shay møder en aktivist tæt ved den base, hvor han arbejder med beregninger på forskellige typer våben: „De er bevæbnede, sagde han, og så er vi også nødt til at være bevæbnede«. (U,p. 407) Tonen er nærmest henkastet, som om det er en indøvet formel, der bare lires af. Den epokalt betingede forståelse af oprustningens nødvendighed forekommer i det ene historiske øjeblik tung som en skæbne og i det næste let som en fjer. Igen handler det om den store histories porøse karakter ved nærmere eftersyn.

\section{Mordet}

Vendepunktet i Nicks liv, som vel at mærke ikke er et punkt, der ligger ude i en stadig mere fjern fortid, men et sted i identiteten, der er evigt præsentisk - en uopløselig kerne i identiteten - er det mord, han begår som 17-årig på den forhutlede tjener George Manza. Mordet finder sted ved en fatal ubetænksomhed, og Nick sendes på en ungdomsanstalt. Her viser det sig, at det stof, Nick er gjort af, er modtageligt for moralsk forbedring. Han bliver ligefrem skuffet, når anstalten i Staatsburg ikke fremviser en eksemplarisk orden. Den unge Nick internaliserer opdragelsesanstaltens logik, ikke for i det ydre at simulere konformitet med dens krav og dermed slippe billigere, men for at komme videre og overvinde en dårlig begyndelse. Han påtager sig flest mulige fysiske opgaver for derigennem at opbygge sig selv. Han begynder forfra ved at bygge en identitet ud fra »de rutinemæssige bevægelser med skovlen i den dybe sne« $(U$, p. 489). I de opgaver han frivilligt tager på sig, i utilfredsheden med anstaltens uorden og tilfredsheden med de daglige rutiner viser der sig noget i Nicks karakter, nemlig en skyldbevidsthed og et soningsberedskab, der stikker dybere end det straffesystemet nogen sinde 
kunne finde på at forlange af et menneske, der havde begået uagtsomt manddrab. Uanset hvilken »bureaukratisk etiket«, der sættes på, er det mord. Det bliver netop et vendepunkt, fordi han går længere ind i skylden, end systemet tvinger ham til, og dermed ikke accepterer den officielle juridiske fortælling, som kan lægges slørende hen over hans handling. Uanset »hvordan man betegner det« $(U$, p. 489), er det drab. De lindrende og skyldsunddragende eufemismer, som det officielle sprog stiller til rådighed, er fra Nicks synspunkt en fælde, der kan forhindre ham i at komme videre i livet. Han gør mordet til en del af sin fortælling.

Da Nick tyve år senere på en bar i New York møder en ven fra barndommen, der sidder fast i sit usle og udsigtsløse liv, tænker Nick på sin kontante facon: »og alt sammen fordi han aldrig har dræbt en mand«. (U, p. 603) Vennen har aldrig været nødt til at gøre status og lever derfor sit liv som en ureflekteret kontinuitet af livet i 1950'ernes boligblokke, som det skildres udførligt i romanens næstsidste afsnit. Hele baren bliver i Nicks bevidsthed til et sted, hvor »indespærrede sjæle« forgæves prøver at slippe fri. Selv stikker han af ved først givne lejlighed.

Men den pris, som Nick selv betaler, er høj. Den stoiske og distancerede livsform, der sikrede ham en udvej, betyder også en fremmedhed i forhold til sin oprindelse. Som »den kunstigt frembragte mand« ( $U$, p. 267) han er, hæfter der også noget dæmonisk og utilnærmeligt ved ham.

\section{Fortællerens sociologiske blik}

Lige fra romanens begyndelse findes en fortællerstemme, der har større ambitioner end blot at gengive den konkrete handling, som udspiller sig for læserens øjne. I pludselige spring og skift udvides handlingens horisont med henvisninger til steder og mennesker, som ikke skildres på en individualiseret måde. Det publikum, der er på vej til kampen mellem Giants og Dodgers, beskrives som "mænd med blød hat og sømænd på orlov« $(U$, p. 7$)$, og det almene ved kampen understreges kun yderligere, da de mænd, der sælger vimpler og kort, omtales som "radmagre mænd der faldbyder emblemer og kasketter, alle er spredt nu, gået hjem til deres små værelser i de håbløse gader«. (U,p. 8) Der spores en tendens til, at fortælleren forestiller sig det typiske og almene bag ved det individuelle og konkrete. Dette typologiserende »sociologiske« blik, der sammenfatter gader, værelser og profession i nogle få bemærkninger, gør sig gældende gennem hele romanen.

Nicks oplevelser med lufthavne kan tjene som illustrativt eksempel. Han erindrer sig den menneskelige adfærd i en lufthavn. Den lufthavn, den bagageudlevering, den menneskemængde, der omtales, er trods den bestemte form, ikke et bestemt sted, men nævnte lokaliteter som sådan i 
deres globale ensartethed. Nick uddrager det gennemgående i mange ensartede oplevelser, f.eks. menneskemængdens adfærd. Det er et ekstrakt af et utal af konkrete oplevelser samlet, dvs. gjort til almen erfaring. Både hos fortælleren, Nick og andre af romanens personer glider blikket af på det konkrete og ser omridset. Det viser sig f.eks. i lidenskabsløse opremsninger: »få børn, købe et lille hus, huske alle folks fødselsdage, køre en tur på Blue Ridge Pakway, blive syg og dø». (U,p. U,p. 300) Den iterative fremstillingsmåde, der ikke beskriver én bestemt situation, men sammenfatter flere situationer på en måde så de fremstår som én, kulminerer det sted hvor Nick gør status over sit liv. Således sammenfatter Nick sit liv som kosmopolitisk symbolanalytiker:

»Hos Waste Containment er jeg blevet en slags emeritus-direktør. Jeg tager ind på kontoret nu og da, men for det meste rejser jeg og taler. Jeg besøger universiteter og forskningsinstitutioner hvor jeg bliver præsenteret som affaldsanalytiker. Jeg fortæller dem om de forladte militærbaser som bliver omdannet til affaldsdepoter, om bunkersystemet under et bjerg i Nevada som måske og måske ikke kommer til at rumme i tusindvis af ståltromler med radioaktivt affald i ti tusind år. Så spiser vi frokost. (...), og jeg flyver til London og Zürich for at deltage i konferencer i regn og slud«(U, p. 782).

I opremsende jeg-sætninger sidestilles radioaktivt atomaffald, frokostspisning og regnvejr. I nivelleringen mellem afgørende ting og banal hverdag, udtrykkes leden ved en monoton tilværelse. Ingenting bliver individualiseret, tværtimod betones det isolerede og tilfældige. Man har fornemmelsen af, at det lige så godt kunne være nogle andre europæiske byer eller et helt andet bjerg i Nevada, og at intet kunne interessere Nick mindre. Sammenfatningen er en træt henvisning til noget, Nick har oplevet hundredvis af gange, og tonen er næsten vrængende. Den almengørende gentagelse vidner ikke bare om fortællerens stil og teknik, men om Nicks bevidsthedsform. I dette tilfælde falder den iterative fortællestil sammen med en melankolsk og lettere indifferent stemning.

Der er en indbygget tristhed i denne almengørelse af det konkrete liv, som f.eks. også kan genfindes på Edward Hoppers billeder af amerikansk hverdag i biografens foyer, ved benzinstationen, i baren eller på en forretningsgade søndag morgen. Blikket gennemlyser og fremmedgør det velkendte til det almene og almindelige. Således opstår der formuleringer, hvor der sniger sig en fremmedhed ind i det velkendte og fortrolige. Eller for at citere sidste sætning i Underverden: "...her i deres egne fjerne og almindelige gader« $(U$, p. 760). Renset for særpræg, anonymiseret til genkendelig almin- 
delighed og gjort upersonligt, træder virkeligheden frem som kondenseret tristhed: Tilfældig og almen. Et sted tales om en "sammenklappelig kendsgerning der er foldet sammen«. (U,p. 30) De kendsgerninger, situationer og hændelser, der optræder i Underverden, har ofte karakter af at være blevet foldet sammen.

\section{Sjælens teknologi}

I modsætning til Nicks måde at gøre status over sit liv på, kan man i portrættet af FBI-chefen Edgar Hoover se et portræt af et menneske, der lyver, ikke mindst for sig selv. Hoover beskrives som en mand med en kreativ evne til at sublimere sin latente homoseksualitet. Det gør sig f.eks. gældende når han bor sammen med sin nærmeste medarbejder Clyde på hotel og placerer et spejl således at han kan se Clyde nøgen. Spejlet er placeret så det »ville virke helt tilfældigt hvis emnet skulle blive klar over at han blev iagttaget, og en tilfældighed ikke blot fra hans synsvinkel, men også i Edgars tanker«. Spejlets placering gør det ikke bare muligt at skjule hensigten for Clyde, men også for hans egne bevidste tanker. Det der beskrives er, hvordan Edgars sind fungerer via rationaliseringer, der iscenesætter forbudte drifter som uskyldige tilfældigheder. Jürgen Habermas sammenfatter en afgørende lighed mellem hverdagens psykologi og det politiske på følgende måde:

„Fra hverdagens erfaringer ved vi, at ideer ofte tjener til at stille retfærdiggørende motiver for vores handlinger i stedet for de virkelige. Det som på dette niveau kaldes rationalisering, benævner vi på den kollektive handlings plan ideologier. I begge tilfælde er det manifeste indhold af udsagn gennem en ureflekteret binding til interesser, forfalsket til en kun tilsyneladende selvstændig bevidsthed «. ${ }^{2}$

Rationalisering og ideologi er fælles om at være retfærdiggørende fortællinger. Både på det individuelt-psykologiske og det kollektivt-politiske plan findes et narrativt behov for at stilisere og homogenisere modstridende fakta til én historie. De dele af Underverden, der direkte kommenterer epokens globale historie - hvilket er et minimum i forhold til de mange livshistorier - er fyldt med beske kommentarer til det, der ikke bliver fortalt eller bevidstgjort i den herskende selvforståelse, som er tæt knyttet til Den kolde

2. Jürgen Habermas: „Erkenntnis und Interesse«, in Habermas: Technik und Wissenschaft als »Ideologie«, Frankfurt a. M. 1968, pp. 159-60. 
Krigs paranoide historier. De demonstranter, der angriber FBI-chefen Edgar Hoover ved ballet på Plaza Hotel i New York iført masker af asiatiske barneansigter oversmurt af blod og som dermed fortæller en ubehagelig historie om Vietnamkrigen, udtrykker, hvad romanen selv gør. Ja, romanen kan groft sagt opfattes som en sådan asiatisk barnemaske.

Som antydet kan Nicks måde at gøre status over sit liv på opfattes som en model for romanens historiesyn på det kollektive niveau. Et historiesyn, der dykker ned under rationaliseringerne og ideologierne med deres tabuering af dissonante erfaringer. Men det ville være en misforståelse at stoppe her i en udlægning af romanen og konkludere, at den kun fortæller ugens ufortalte historier, som det siges af komikeren Lenny Bruce ( $U$, p. 608). Det ufortalte har måske også en ufortællelig eller dunkel side. For det første fortælles den store historie kun, når den i en alvorlig, tragisk eller komisk tone undergraves. For det andet fornemmes yderligere et lag i beskrivelsen af de politiske og historiske begivenheder, der henvises til.

Romanens mest komplicerede og fortættede formuleringer falder i forbindelse med kommentarer til Kennedymordet. Her falder knappe henvisninger til noget andet inde i det velkendte, som det er svært at lodde dybden og betydningen af. Ved en privat forevisning af Zapruders berømte optagelse af skuddene mod Kennedy bliver Klara Sax meget spekulativ. Det er ikke de evigt cirkulerende konspirationsteorier, der interesserer hende, men filmens »indre liv« (U,p. 481). Den død, som filmen viser, beskrives som noget der kommer fra »sjælens nat«, som »bevidsthedens genfærd», som et billede af "sjælens egen teknologi« og gennem andre næsten uigennemtrængelige ordkonstellationer. Men hvad har bevidsthed og sjæl med Zapruders film at gøre? Svaret falder formentlig sidst i afsnittet. Filmens billeder af et attentat er "en model af de nætter hvor vi er fortrolige med vores egen død« $(U, \mathrm{p}$. 481). Filmen bliver til en påmindelse om den private og alment forestående død neden under det til bevidstløshed gentagede politiske mord. Klara Sax' tanker løber i samme baner, da hun ved en societybegivenhed i sommeren 1974 overværer en forevisning af en anden film, nemlig Sergej Eisensteins i mange år forsvundne film Unterwelt. Filmen udspiller sig i grotter, klippespalter og kældre, og Klara har en fornemmelse af, at filmen er uden »socialt motiv«. (U, p. 418) Tværtimod bliver den tolket som udtryk for en politisk holdning, der er »mere intim«(U,p. 431) og handler om »tilværelsens modsætninger« $(U$, p. 432$)$.

Don DeLillos roman er om noget et politisk værk om den sociale og politiske historie, men i dette som i andre tilfælde er det ikke nødvendigvis det politiske, der får det sidste ord. Den politiske virkelighed er ikke den endelige sandhed om f.eks. Kennedymordet. Under det politiske mord er der yderligere et lag. Der er vel at mærke ikke tale om en nedskrivning af det 
politiske til det almenmenneskelige, men om en pointering af, at det eksistentielle og psykologiske er et lag $i$ det politiske. Når navigatøren Charlie Wainwright bomber civilbefolkningen i Vietnam, føler han samtidig en »hævngerrig fornøjelse« $(U$, p. 594), der giver ham oprejsning for hans egne nederlag. Længere væk er den personlige historie åbenbart ikke fra den politiske historie.

\section{Romangenren}

Underverden er en roman, der bedriver kritisk erindringsarbejde og undersøger Den kolde Krigs selvforståelse i amerikansk sammenhæng. Den gennembryder som antydet selvforståelsen, når den antager karakter af rationalisering eller ideologi. Romanen praktiserer med en formulering af forfatteren Milan Kundera »en bevidst, stædig, indædt ikke-identifikation «. ${ }^{3}$ Romanens form for tænkning er åben og eksperimenterende: »den åbner sprækker i alle de idésystemer, som omgiver os«(U,p. 155). Genrens force er således ifølge Kundera, at den giver tanken mulighed for at vende sig mod sig selv og gå bag om holdninger og overbevisninger. Centralt i Kunderas beskrivelse af romanens historiske egenart står, at den er for eksperimenterende og subversiv til at være loyal mod nogen som helst ideologi, og som sådan er romangenren den kritiske tankes hjemmebane.

Efter en episode hvor Nick har fortalt sine mest private og intime tanker til en fremmed kvinde, griber fortælleren autoritativt ind og samler trådene: »Du skjuler de dybeste ting for dine nærmeste, og taler så med en fremmed på et nummereret værelse« $(U$, p. 292). Ikke i det nære og velkendte, dvs. det forpligtende, men i det fremmede, kan tingene siges som de er. Fiktionens anonymitet fungerer på samme måde som et slags vidnebeskyttelsesprogram, der gør det muligt at formulere prekære kendsgerninger og sandheder, som netop der kan cirkulere friere end i f.eks. en offentlig politisk samtale. Litteraturen er en offentlig tale eller henvendelse, der nyder nogle af de privilegier, der normalt er forbeholdt private samtaler og kan som sådan fortælle den historie, der »lever i intervallerne mellem den officielle kommentar«. ${ }^{4}$ Romanen har et rationaliserings- og ideologikritisk potentiale og kan med sin ikke-identifikation med det politiske, gennembryde de sociale omskrivninger og således forny den politiske samtale med et input som ofte ikke kommer til udtryk. Trods Don DeLillos ambition om f.eks. at ramme en særlig sprogtone og jargon fra perioden i bestemte miljøer, kan Underver-

3. Milan Kundera: De forrådte testamenter,(org. 1993), Kbh. 1996, p.140.

4. Kundera op.cit., p.23. 
den ikke gøre krav på at være et historisk dokument om Den kolde Krig og dens mange underhistorier i streng forstand. Men ikke desto mindre rammer den ind i hjertekulen af brudflader i epokens historieskrivning om sig selv. Romanen er ikke objektiv, men en kritisk refleksion over det angiveligt objektive, dvs. de officielle virkelighedsfortolkningers delvist fiktive træk.

\section{Historiens substans}

Don DeLillo er først og fremmest en historiefortæller, der er gået på jagt efter den amerikanske identitet. Ikke for masochistisk at gnide i den nyere amerikanske histories åbne sår med dens politiske mord, Vietnamkrig, Watergateskandale og meget andet - som det f.eks. er tilfældet hos filminstruktøren Oliver Stone - men for at skrive sig ind til en forståelse af det amerikanske hverdagsliv. I Underverden har Don DeLillo blik for hele spektret i det menneskelige: Lige fra det alment genkendelige billede af bananer, der bliver brune i vindueskarmen, og den voksnes trang til som i barndommens sommerdage at drikke af en haveslange, til en skildring af de psykologiske og ideologiske forudsætninger, der gjorde det muligt at få nogen til at læsse tonsvis af bomber ud over bondebefolkningen i Vietnam.

I Don DeLillos katastroferoman, Hvid støj, findes et replikskifte, der anskueliggør, at der går fine røde tråde mellem stort og småt i livet. Talen falder på dødsangst, men dødsangsten er måske ikke helt det, den giver sig ud for. For som den ene siger til anden. "Måske har du bare et personligt problem, der dukker op til overfladen i form af et stort universelt tema (...) »Noget du skjuler for dig selv. Din vægt måske«. ${ }^{5}$ Det er selvfølgelig lidt komisk at vægten skulle være en drivkraft i dødsangsten. Det er komisk, men også alvorligt. Det, der forekommer at være et grundlæggende problem, angsten for døden, der venter forude, eller andre tilsyneladende store eksistentielle temaer, har ikke kun eksistentielle kilder, men kan være en forklædning af problemer, der hører til i småtingsafdelingen. Dødsangsten er den store metafysiske fortælling, der ved et nærmere blik fortæller mange små historier. Men ingen historie - personlig, politisk-historisk eller metafysisk får lov til at få det sidste ord; den ene historie er ikke den anden histories substans, men dens uddybning og supplement. Læst således handler romanen paradoksalt nok også om, hvor nemt det er er at overvurdere den store histories betydning, generalernes, præsidenternes og revolutionernes, altså det, der gled over TV-skærmen når man kom træt hjem fra arbejdet i den

5. Don DeLillo: Hvid støj, på dansk ved Jørgen Nielsen, (org.1984), Kbh. 2000, p.240. 
lokale skoles cafeteria. Set fra midtvesten ser Cuba-krisen således ud i Lenny Bruces gengivelse:

»Hendes arbejde består i at servere hamburgere i skolens cafeteria, og hun kommer udmattet hjem og tænder for fjernsynet, og det er De Forenede Staters præsident, og han siger: Ødelæggelsens afgrund. Og der sidder hun i sin hvide cafeteriekittel, med skoene af, og piller tæer. Hun hedder Bitty. Hun tænker at de har taget Lawrence Welk af programmet for at denne irsk-katolske millionær kan tale om ødelæggelsens afgrund « (U, p. 493).

Den store historie er her stikord i baggrunden af hverdagens små foreteelser blandet op med en ind groet mistillid til og ressentiment mod den hvide overklasse, der styrer krisen. Den centrale placering som fjenden, russerne, indtager i den officielle udlægning af Cuba-krisen, er end ikke repræsenteret i kvindens bevidsthed. Det er denne historie under historien, denne »undererindring« $(U$, p. 60), om verdens mulige undergang, der ofte står i centrum i Underverden, uden dog at være den endelige historie, dvs. sandheden. Historierne fremstilles snarere som forskellige bearbejdninger af det samme, men hvad det samme nøjagtigt er, er ikke nemt at sige. Som det antydes i mottoet til denne artikel er det måske ligefrem selve strukturen eller logikken ved historier og fortællinger som sådan, fortællingens underverden, der undersøges. Historiernes dunkle substans er det, der skaber dem. Igen og igen søges der bygget »troværdige verdener« oven på det ukendte. Utallige gange vendes tilbage til det øjeblik, hvor Nicks og Matts far gik ud efter cigaretter, men aldrig kom tilbage og derfor overlod sønnerne til deres egne fantasifulde fortællinger om årsagerne til hans forsvinden. I den forstand skaber nogle få simple fakta »en historie uden en slutning« ( $U$, p. 304).

For den der burde kende Nick bedst, konen Marian, fremstår hans stoicisme som dunkel dæmoni, som en ubestemt »kraft af en eller anden art«. (U,p. 252) Hun konstaterer, at der er »noget hårdt og anderledes« (ibid.) ved Nicks væsen. Der er noget som driver historierne - store og små - men som ikke er identisk med historierne selv, en uopløselig kerne. 